\title{
An Assessment of Public Private Partnership and Social Service Reform in Nigeria: 1999-2007
}

\author{
Article by Nebo Sandra Ogochukwu ${ }^{1}$, Nnamani, Desmond Okechukwu ${ }^{2}$ \& Ituma, \\ Afam. $\mathrm{O}^{3}$ \\ ${ }^{1}$ Dept of Business Administration \& Entrepreneurship Federal University Ndufu-Alike \\ Ikwo \\ ${ }^{2}$ Dept of Public Administration \& Local Government University of Nigeria, Nsukka \\ ${ }^{3}$ Personnel Unit, Godfrey Okoye University Enugu \\ Email: connectogoo@yahoo.com
}

\begin{abstract}
The provision of infrastructure in any developing nation especially third world countries is the backbone of the country's national economy. The government at all levels is responsible to provide infrastructure via dependence on loans and credits from financial institutions, the requirement for the infrastructure deficit is such that cannot be met by relying on the public sector to boost public investment without increasing public borrowing. The exclusive funding of social services in Nigeria was a challenge in early 80s; the economy co-opted International Monetary Fund (IMF) and Structural Adjustment Programme (SAP) to disengage social service delivery. The premise of global economic meltdown declined the revenue base and source of income as a means of funding social services in Nigeria. Public Private Partnership initiative has the prospect to attain financial constraints to improve the framework for business environment. The paper examines the link between PPP and social service delivery in Nigeria, and recommends that government should put more efforts to improve the level of awareness on the involvement of private sector in the provision of infrastructure through public enlightenment locally and internationally stating the benefits both for citizens and investors.
\end{abstract}

Keywords: Social Service, Revenue, Policy, Financial crises, Reforms.

\section{Introduction}

A public private partnership is a government service or private business venture which is funded and operated through a partnership of government and one or more private sector companies. These schemes are sometimes referred to as P3 (Abubakar, 2013). The public private partnership involves a contract between a public sector authority and a private party, in which the private party provides a public service and assumes substantial financial, technical and operational risk in the project. In some types of PPP, the cost of using the service is borne exclusively by the users of the service and not by the taxpayer (Barlow and Wright, 2013). In other types like private finance initiative, capital investment is done by the private sector on the basis of a contract with government to provide agreed services and the cost of providing the service is wholly or partially done by the government. The government contributions to PPP may be in the transfer of existing assets on projects aimed at creating public goods like in the infrastructure sector, the government provide a capital subsidy in form of grant, so as to make it more attractive to the private investors. In some cases, the government support the project by providing revenue subsidies like tax breaks or removing guaranteed annual revenues for a fixed time period. The two fundamental drivers for PPPs enable the public sector to harness the expert efficiency the private sector can bring to the delivery of certain services traditionally procured and delivered by the public sector (World Bank, 2007). The PPP is structured to make the public sector a capital investment not to incur any borrowing. Instead the PPP borrowing is incurred by the private sector as a vehicle for 
South American Journal of Management

Special Edition 2016

implementing the project to the public sector perspective, PPP is an off-balance sheet method for financing the delivery of refurbished public sector assets (Virginia and Allen, 2012).

According to Abubakar (2013), the logic for establishing PPP is for public and private sector to have unique characteristics that provide them with specific aspects of service delivery. The successful partnership arrangements draw the strengths of the public and private sector to establish complementary relationships. The responsibilities of the partners may vary from one project to another for example, in some projects, the private sector partner are involved in all aspects of service delivery while in others the role of private and public sector partners differ on individual servicing initiatives, but the overall roles of government do not change (Colman, 2002). Public private partnership is one way of delivering public infrastructure and related services, it is not a substitute for effective governance and decision making by government. In all cases, government is responsible and accountable for delivering services and projects in a manner that protects and furthers the public interest. Typically, a private sector consortium forms a special company called "special purpose vehicle" (SPV) to develop, build, maintain and operate the asset for the contracted period (Zhen and Lewis, 2008). In cases where the government has invested in the project, it is but not always allotted an equity share in the SPV (Moszoro 2008). The consortium is made up of a building contractor, a maintenance company and bank lenders. It is the SPV that signs the contract with government and with sub-contractors to build the facility and then maintain it. In the infrastructure sector, complex arrangements and contracts that guarantee and secure the cash flows make PPP projects prime candidates for project financing. A typical example of PPP is a hospital building financed and constructed by a private developer and then leased to the hospital authority. The private developer then acts as landlord, providing housekeeping and other non-medical services while the hospital itself provides medical services (Burnett, 2007). In Nigeria, the social service is in a dire state because this inhibits investment and scale up the cost of business management (FGN, 2004). Inevitably, the paper explores factors that undermine the goals of Public Private Partnership initiative on the framework of Nigeria development quest.

\section{Clarification of concepts}

\section{Public private partnerships}

Public-private partnership (PPP)is an alternative method for the delivery of infrastructure and services in different parts of the world (Dada \& Oladokun, 2008). PPP depicts a government service or private business venture funded and operated through a partnership of government in one or more private sector companies. These schemes are sometimes referred to as PPP or P3 (Harris, 2008). According to Cheung (2009)PPP is a procurement approach where the public and private sector join forces to deliver a public service or facility, expertise and resources are contributed by partners to the project and risks involved are share amongst them. Egbewole (2011) explains that the private sector partner becomes involved in the development, financing, ownership and or operation of a public facility or service. PPP arrangements come in many forms but two categories are in use that is identified as institutionalized and contracting arrangements (Gunnigan and Rajput, 2010). The variants of PPP arrangements used for existing services and facilities procurement are Design-Build (DB), Design-Build Maintain (DBM), Build-Transfer Operate (BTO), and Design-BuildOperate-Maintain (DBOM)known as Build-Operate-Transfer (BOT). Some models such as Service contracts, Management contracts, Lease, Concession and Divestiture are use for infrastructure procurement.

Social Service: is a set of program aimed at achieving some objectives and it relates to the social system in the goals of social policies. All social policies are directed towards change not only in the structure of society but for the living conditions of the people in the society. Social service programs are services provided by a governmental agency for welfare of persons or the community at large such as housing, child protection, free education and health care delivery. Social service programs and their delivery help the people with necessities to 
attain self actualization and happiness (Ayo 1988). Social service encompasses improvement in the social status of the people and society in general. It necessitates in reality and not deceitful the provision of such services as health, education, housing, roads, portable water and electricity. It encompasses the "reduction of poverty, improvement of women and workers"(Olewe and Anga, 1994:165). Geol (1981)states that social service is a process of bringing community welfare through social change and the implementation of social policy decisions for the total welfare of the community. It encompasses every act, technique and consideration in the process necessary to transforming social policy. Donnison (1968) also states that during social services delivery, social legislation aimed at private philanthropy and religious charities into the dynamics of services and benefits for humanity are implemented. Currently, Nigeria has weak state supported social welfare system; hence, most people rely on the extended families in their old age. The medications are provided for government employees and few company workers in commercial enterprises while the rest of the populations are left on their own. Nigeria lack state supported social services system to support her citizens on emergency. Arguably, Nigeria's fiscal arrangement to the three levels of government has problem of coordination in social service delivery.

Reform: connotes "change", "improvement" in a given condition or state of affairs, change toward better conditions, it is synonymous with progress. Olewe (1995:2)states that reform is to bring ideas, plans, programmes into reality. Put differently, reform is the national transformations that aid positive changes. Everett (1989:841)described economic reform as a widely participatory process of directed social and economic change in a society, intended to bring about social change and material advancement like equality, freedom and other valued qualities for the majority of people through their gaining greater control over their environment. Thus, a good social service reform will bring national renewal through systematic and faithful implementation in the polity. It seeks to change the status quo that ought to be changed. It requires proper planning and implementation, if desired ends are to be attained. The economic reform is a planned process of bringing about improvement in a socio-economic and political order in a polity. The purpose of socio-economic reform is a comprehensive program of government geared towards transforming the structures and systems of public service for improved service delivery.

\section{Types of public private partnership: nigerian Experience}

The public private partnership initiative can be delineated from the current operation in Nigeria, the infrastructure development and revenue generation in which private sector collect revenue for state and local government seems to be a waste for instance the Obasanjo administration in managing capacity building for federal unity schools on information communication technology (ICT) and tax administration. Mabogunje (2007) identified that the seven types of public private partnership overlap in some cases; the variants of Public Private Partnership differ in allocation of responsibilities and risks between the state, private sector and duration. The seven types of PPP are build, own and operate (BOO), which makes the government to authorize private firms to build, own and operate an asset; Build, operate and transfer (BOT) is similar to BOO, but differs from it to the extent that the asset is transferred to the government after a period of time, reasonably enough for the private investor to recouped its investment; contracting out the provision of certain technical services by public sector to an external private company; concession of private firm for operating a service and collecting charges for a period of time. Aftermath, the public sector controls the construction and owns the fixed assets but contracts out to private sector organizations operation, maintenance and collection of service charges; leasing involves that one of the partners use equipment or assets belonging to either of them without purchasing the assets but pay a lease to the other partner. The private sector takes over the operation of the infrastructure using capacity of the public sector. The variants of Public Private Partnership initiative according to Mabogunje is concession by the dominant type operation. The reconstitution of infrastructural concession regulatory commission (ICRC)by President Umar 
Yar'adua took a strategic step to overcome the infrastructural deficiency. The ICRC act was endorsed by President Obasanjo in 2005 to enhance private sector participation in financing development projects of federal tier through contractual arrangements. The infrastructure and human development investment is co-opted in 2009 budget of Yar'adua administration achieves a lot in this regard (Budget Speech, 2009). A typical example is Public Private Partnership initiative of 30 year old Lagos-Ibadan expressway conceded to Bi-Courtney highway services for managing 110 kilometer expressway, Lagos-Ibadan express-way, ancillary facilities for trucks, areas of convenience and communication equipment for road users. The manager Bi-Courtney Limited is expected to source N89.53 billion to prosecute the turn-around project executed on Build, Operate and Transfer (BOT)arrangement span for 25 year period. The investment on the project will be recovered through tolls to be charged on the highway subject to regulatory guidance from the federal government. The rehabilitation of Murtala Muhammed Abuja International airport with Messers Bi-Courtney Consortium, and two run ways in the airport and the outer expressway from Zuba through Kubwa to Asokoro in FCT, Abuja. The federal government will provide $40 \%$, contractors will source for $60 \%$ cost of the project during which if completed will generate 25,000 job to boost commercial activities within and around Abuja. The reconstruction of second Niger Bridge in Onitsha will gulp N4.3 billion counterpart funds and Guto-Bagana Bridge across River Benue. The federal government will mobilize them with N3.6 billion funding through PPP arrangement (Budget speech, 2009). Consequently, the PPP initiative road projects are Shagamu-Benin, LagosBadagry, Abuja-Kaduna-Kano roads. The National Food Reserve Agency (NFRA) adopts the initiative to manage silos and reservation facilities. The completion of the projects was not captured and this will go a long way to make Nigeria an investment destination for the conditions of its citizen.

\section{The framework of PPPs}

PPP involves public and private sectors in partnership with each other (Harris, 2003). This is a partnership between public sector and private sector investors for the purpose of designing, planning, financing, constructing, and operating infrastructure facilities or related services.

PPPs build on the experience of each partner to meet defined needs and provide a net benefit to the general public through appropriate allocation of resources, risks and rewards (Leiringer, 2003). It unbinds the costs and the risks inherent in to deliver the project and allocate them to the partner and absorb them. The ability of public and private sector to partner effectively mitigates each to govern the allocation of risk. Public organizations engage private sector in many ways such as contracting for manpower, service outsourcing. PPP work with private sector to deliver services particularly in the development of new physical assets, it refers to long-term partnering relationships between the public and private sector to deliver services.

In PPP, the private sector provides a wider range of services over a long contract period between 15 and 30 years (Harris, 2003). This came through collaboration with private sector; public services can be delivered in value for money by making optimal use of the public and private sectors expertise, resources and innovation to meet public needs effectively and efficiently. The reason for establishing such partnerships vary but generally involve the financing, design, construction, operation and maintenance of public infrastructure, facilities and services. In other words, PPPs are not just about private sector financing capital projects in return for an income stream, but the use of private sector skills and management expertise to deliver and operate public projects more efficiently over their lifetime. The underlying logic for establishing partnerships is that public and private sector has unique characteristics that provide them with advantages in specific aspects of service delivery (Leiringer, 2003). The most successful partnership draw public and private sector to complement relationships, while the responsibilities of the private and public sector partners differ on individual servicing initiatives, the overall responsibilities of public sector do not change. 
PPP is one way of delivering public infrastructure, facilities and related services. It is not a substitute for strong and effective governance and decision making by government. In all cases, government remains responsible and accountable for delivering services and projects in a manner that protects and furthers the public interest (Chan et al., 2008).

\section{Theoretical framework}

The framework adopted for this paper is the theory of dualism as propounded by Professor Boeke of Netherlands in 18th century, when the western style of agricultural plantation was introduced by the Dutch in Indonesia, and this was discovered after few years of western system that plantation failed woefully (Skills, 1972;459). The theory argues that economic laws valid in advanced capitalist nations may not work in underdeveloped countries. The social service in capitalist nations facilitates development in an environment with appropriate institution and value system. The theory contends that western strategy of socio-economic development in 3rd world countries are characterized by:

- Enthusiasm and high expectation,

- Resource are mobilized for its success,

- Government justify through massive propaganda network,

- Little success is achieved in the implementation process,

- The economic condition of the people deteriorates,

- The government is more authoritarian to survive (Ujo 2007:5).

The Marshal Plan led to the reconstruction of Western Europe within few years after $2^{\text {nd }}$ world war was adopted for the development of post-colonial African states did not succeed. The development strategies of United Nations Development Decade, New International Economic Order and the Brandt Report did not achieve result in Africa. The structural and attitudinal factors that negate development process were on the Western strategy based on poor basic institutions, inadequate manpower, corruption, non value system. Some scholars like Riggs (1974); Whitaker, (1970) confirms the theory of dualism in Nigeria economic policies in relation to democratic process are:

- The basis of the policy is on western development strategy.

- Massive resources were deployed for its success.

- Propaganda mechanism of state was mobilized for success.

- The policy makes few Nigerians rich and majority poor.

- The pace of poverty level between 1999 and 2009

- Most industries closed down due to unemployment.

- Social services like power, water and roads have deteriorated.

- There is a steady rise in anti-social activities.

- There is a big wave in armed robbery

- Corruption was on the increase (Ujo, 2007:5-6)

In the contemporary political and economic systems most 3 rd world countries adopted the Western strategy of socio-economic development with the hope that development will occur. The structural institutions and behavioural factors in realizing the strategic aims were impossible because the institutions are weak. These two tendencies exist in 3rd world countries and the economies and politics of underdeveloped countries must consider the two factors (Ujo, 2007:4).

\section{Public private partnership development in nigeria}

The primary agent for development with little or no role assigned to the Private sector in the development is endowed in the Public sector with the dominant role of developmentalism to political economy of post-colonial Africa in early 80s (Mabogunje, 2007, Olukoshi, 2003). The state enterprises own by the state could not impact to the development of the economy despite huge capital investment in operation. Accordingly, successive regimes in Nigeria invested N800 billion in these enterprises while the annual returns was below $10 \%$ of the investment capital (BPE, 2000). 
South American Journal of Management

Special Edition 2016

The exclusive state of infrastructure continued in Babangida administration through Directorate for Food, Roads and Rural Infrastructure (DFRRI)to improve rural dwellers, but in 1987, DFRRI received a budgetary allocation of N400 million while N500 million was allocated to them in 1988 to improve on the development of agriculture in rural areas. The budgetary votes to DFRRI states that the agency received higher allocation than most ministries and parastatals in Nigeria for instance, education ministry gets N4 million in 1987 and N3.02 million in 1988. Similarly, health ministry got N166.9 million in 1987 and N259.9 million in 1988. It was only in defence ministry that voted N717.6 million in 1987 and N830 million in 1988 higher than DFRRI (Ake, 2001). The signs of the waning capacity as the sole provider of infrastructure finance began to manifest in 1983, with the economy having a serious crisis. This crisis has severe depth since the creation of Nigeria-state as Anglocolonial project (Bangura, 1982),

Nigeria witnessed decline in capacity for social and infrastructure provision; this led to increased legitimacy crisis of the state (Jega, 2000, Amin, 1996). The oil boom enhances legitimacy through massive public expenditure in critical sectors of the economy like construction, commerce, industry, banking and social service delivery. The collapse of global oil market in early 80s brought sharp reduction in oil earnings from N10.1 billion in 1979 to N5.161 billion in 1982. This spawned a major crisis with many industries closed down, while some operate below installed capacity utilization (Olukoshi, 1993). The economy slides in the crisis over the increase percentage of budget deficit grew to $12 \%$ GDP in 1983, all efforts to stabilize the tide of economic crises act of 1982 during Shagari administration in Nigeria. The World Bank adopts Structural Adjustment Program in July 1986 (Ake, 2001), the implementation of SAP adjusts the need to generate surplus to pay their debts and restructure the economy along neo-liberal lines (UNRISD, 1995). The reduction in public expenditure is a major component and funding of infrastructure adversely affects the decline of SAP (Ake, 2001 Kukah, 1999).

Public Private Partnership as initiated by President Obasanjo is an economic reform to shift from socialist character economy to free market economy with neo-liberal policies of deregulation, privatization, monetization and right-sizing of public bureaucracy as policy agenda of the government. In these reforms, state utilities were crippled dysfunctional with corruption, inefficiency, indebtedness with no audit account for decades. The anniversary of civil rule in Nigeria indicates that federal government had about 600 state enterprises in all sectors of the economy. Most of them are in a parlous state with unimpressive records of under-performance, a drain-pipe to national treasury (FRN, 2000). Most public infrastructure suffered state neglect leading to infrastructural decay on social service delivery. Most scholars and practitioners blame social service delivery on poor funding in states and local government from federation accounts. The budgetary allocation from 1999 to 2007 in 36 states of Nigeria and Abuja, and 774 local government councils reveals that Nigeria is running an un-federal fiscal federalism. The oil producing states feel marginalized as most of the resources from oil proceeds are meant for the central authority while few percentages are for the host communities. The internally generated revenue of the oil producing states could not attend to their development needs and this situation applies to other states. The high concentration of federal wealth to central government has bogged down national development in Nigeria. The federal government in providing social services nationwide assumes more responsibilities like shelter, roads, transportation facilities; water supply amongst others is the exclusive power of federal tier. Inevitably the functional responsibilities outweigh the available resources in line with fund from the federation account. The internally generated revenue of the states and local governments and federal money are not enough to match the responsibilities of social services.

Financial positions of three tiers of government between 1999-2007

\begin{tabular}{|l|l|l|l|l|}
\hline Year & Fed. Govt & 36 States \& FCT & LG \&FCT & Total \\
\hline 1999 & $154,633,681,769.66$ & $89,719,045,266.37$ & $41,936,047,771.85$ & $131,655,093,038.22$ \\
\hline
\end{tabular}


South American Journal of Management

Special Edition 2016

\begin{tabular}{|l|l|l|l|l|}
\hline 2000 & $531,612,593,116.78$ & $348,291,513,603.64$ & $167,160,070,675.78$ & $515,451,584,279.42$ \\
\hline 2001 & $723,920,377,511.08$ & $465,401,088,573.90$ & $197,546,513,263.92$ & $662947,601,837.82$ \\
\hline 2002 & $782,930,627,493.69$ & $441,784,920,342.94$ & $321,324,219,934.25$ & $763,109,140,277.18$ \\
\hline 2003 & $739,208,155,737.65$ & $557,887,744,033.25$ & $396,799,689,065.92$ & $954,687,433,099.16$ \\
\hline 2004 & $967,234,322,035.71$ & $808,724,985,148.80$ & $515,7177,202,778.67$ & $1,324,442,187,927.47$ \\
\hline 2005 & $1,229,871,999,841.18$ & $1,087,280,283,065.75$ & $617,927,219,631.91$ & $1,705,207,502,697.66$ \\
\hline 2006 & $1,575,681,126,615.67$ & $1,350,456,073,192.49$ & $744,240,741,122.21$ & $2,094,696,814,304.70$ \\
\hline 2007 & $685,596,067,620.30$ & $593,358,190,086.20$ & $310,883,152,307.30$ & $904,241,342,393.50$ \\
\hline Total & $7,390,688,951,768.72$ & $5,742,903,843,313.33$ & $3,313,534,856,541.79$ & $9,056,438,699,855.13$ \\
\hline
\end{tabular}

Source: Revenue Mobilization and Fiscal Commission 1999-2007

Despite the fact that the federal government kept about N7,390,688, 951,768.72, the state received N5,742,903843313.33 and local government received N3,313,534,541.80 from the federation account within the periods from 1999 to 2007 financial years to provide social services to Nigerians, their performance remain poor. The table indicates that fund accruing to the oil-producing states of South-South excluding derivation fund have been constant and relatively small, compared to other geo-political zones of North West and North Central. The distributional inequality is attributed to allocation formula based on land mass. Again, it is pertinent to review the performance of social service delivery since the inception of democratic dispensation.

\section{The place of public private partnership in nigeria}

Public Private Partnership relieves Nigeria from biting effects of global financial crisis even as it gives the private sector a stake in the management of the economy basically on the area of infrastructure provision and management. Neo-liberal scholars contend that private sector offers prospects to developing economies for rapid economic growth in a competitive market conditions (Moran, 1986). However, the efficacy of Public Private Partnership strategy on infrastructure development in Nigeria context to positive factors without which the gains derivable from the initiative becomes elusive. A functional institution is the factor of Public Private Partnership and this significantly shapes the implementation of public policies as they stabilize the process of policy making in Nigeria (Bullock et al, 1983).

The regulation is a factor in public private partnership especially on low-income economies with weak regulatory mechanisms (World Bank, 2000). The World Bank has document on economies with political stability, and the process of altering laws, property rights protection and judicial system preferred investment destinations and record higher economic growth than countries where these attribute are lacking. In the context of Public Private Partnership, institutions are conceived as formal and informal rules that govern the actions of actors in PPP framework (Sampson, 2008).. This institutional infrastructure contains unwritten codes of behavior that encourages cooperation and enforceable legal rules that guarantee the contractual obligations enforced. The existence of institutional framework encourages private investors to provide financial investment required (Oyesiku, 2009).

Consequently, the concession process led to handing over public utilities to private sector managers. All the major stakeholders and users of public assets on concession are involved in the process to allay fears of jobless and prohibitive user charges. This process help to prevent avoidable post-concession protests as witnessed in handing over Tafawa Balewa Square, Lagos and the old domestic terminal of Murtala Mohammed Airport to new private sector managers. The infrastructure concession regulatory commission had a meeting on Nigeria Public Private Partnership program to sustain inputs of stakeholders in the Public Private Partnership process. The Public Private Partnership needs a transparent process necessary to repose confidence among the participants on the initiative with regards to risk sharing. The requisite for transparency in Public Private Partnership process is to improve on the extant regional practice where regimes are not open to international investment agreements (Keet, 2008). 
South American Journal of Management

Special Edition 2016

\section{Conclusion and suggestion}

Undoubtedly, the global financial crisis underscored the collapse of corporate bodies' particularly large financial institutions that constitute global economy. Public Private Partnership (PPP) initiative is a strategy for alternative sources of public infrastructure especially for developing economies. The consequences of economic global meltdown impact negatively on economic development with high rate of unemployment, inflation and crash stock markets. Public Private Partnership is where state openly provides financing of public infrastructure through private sector investment. Public Private Partnership re-defines the role of state in infrastructure provision to transform its status from a provider to enabler in the neo-liberal ideology of market economy. The height of Public Private Partnership rests on the availability of certain positive factors like business environment; regulatory framework and efficient public sector as crucial factors to achieve the gains of Public Private Partnership. The potential of Nigeria as one of the 20 biggest economies in the world offers opportunities for returns on investment; the challenge of Nigeria is to transform this to concrete reality.

\section{References}

[1.] Ayo, B. (1988): "Social Policy in Nigeria's Second Republic: Presidentialism, Politics and administration in a Developing state" Lagos: Daily Times, July 12.

[2.] Abubakar, A (2013): Managing Disasters Through Public-Private Partnership. Georgetown: University Press.

[3.] Babatunde, O, et.al (2012): "Critical Success Factors in Public-Private Partnership (PPP) on Infrastructure Delivery in Nigeria" Journal of Facilities Management. Vol. 10 (3), 212 - 225.

[4.] Barlow, J. and Wright, S. (2013): "Public-Private Partnerships For Building And Managing Health Care Facilities and Services" Health Affairs. 32(1), 146-154.

[5.] Bullock, C. et al (1983): Public Policy in the Eighties, Monterey: Cole Publishing Company.

[6.] Burnett, M. (2007): "PPP Decision Maker Guide" European Institute of Public Administration. 27.

[7.] Chan, A, et.al (2008), "Application of Public Private Partnership (PPP)in Hong Kong Region Perspectives" Proceedings on 1st International Conference on Construction in $2^{\text {nd }}$ Countries, Research and Practice, Karachi, Pakistan, 4 August, 302-311.

[8.] Cheung, E. (2009): "Developing the Best Practice Framework for Implementing Public-Private Partnerships (PPPs) in Hong Kong" PhD Thesis, Queensland University of Technology, Australia.

[9.] Colman, J. (2002): "Mumbo jumbo and other Pitfalls: Evaluating PPP Projects" National Audit Office PPP Conference, London, May 11.

[10.] Dada, M and Oladokun, G. (2008): "Public-Private-Partnership Projects in Nigeria"' in Karter, C. and Ogunlana, S. (eds.), Transformation through Construction: Joint 2008 CIB W065/055 Symposium Proceedings. Edinburgh: Watt University.

[11.] Deloitte Research (2006): "Closing the Infrastructure Gap: The Role of Public-Private Partnerships" www.deloitte.com.

[12.] DFID (2007): "Private Sector participation in Infrastructure Development" www.dfid.gov.uk/pubs/files.

[13.] Donnison, D. (1968): “The Teaching of Social Administration” The British Journal of Sociology, Vol. II, 75-91

[14.] Eboh, E. and Igbokwe, E (2006): "Economic Competitiveness across Nigerian States: The Challenge of Infrastructure and Utilities" African Institute of Applied Economics, Issue 2 BECANS Working paper.

[15.] Egbewole, Q. (2011): "Examining Public-Private Partnership in Nigeria: Potentials and Challenges" LLBEs say, University of Ilorin, Nigeria. 
[16.] Ehebha, L. (2011): “An Appraisal Performance of Public Private Partnership in Provision of Infrastructural Facilities in South West Nigeria" M.sc Project Management Project (Unpublished), University of Lagos, Lagos.

[17.] Esfahani, H. (2005): "Measuring Public Sector Performance in Infrastructure” in Shah, A (ed.), Public Service Delivery, World Bank: Washington, D.C.

[18.] Federal Republic of Nigeria (1999): The Constitution of Federal Republic of Nigeria, Abuja: Government Printers.

[19.] Federal Republic of Nigeria (2000): "President Obasanjo Economic Reform 1999-2003" Abuja.

[20.] FGN (2004): National Economic Empowerment and Development Strategy (NEEDS), Abuja, National Planning Commission.

[21.] Geol, S. (1981): Health Care Administration, New Delhi: Sterling Publishers.

[22.] Gunnigan, L. and Rajput, R. (2011): "Comparison of Indian PPP Construction Industry and European PPP Constructions Industry: Process, thresholds and implementation” Proceedings of CIB World Congress.

[23.] Harris, S. (2003), "Public Private Partnerships for better infrastructure services" A Paper Presented at the Workshop Organized by Inter-American Development Bank in Washington, DC, www.pppcentrum.cz/res/data/001 /000167.pdf

[24.] Keet, D. (2008): “The Role and Impact of Chinese Economic Operations in Africa”, in Guerrero, D. and Manji, F. (eds.), China's New Role in Africa and the South: Search for a New Perspective. Nairobi: Focus on the Global South, 78-87.

[25.] Kukah, M. (1999): Democracy and Civil Society in Nigeria, Ibadan: Spectrum Books.

[26.] Leiringer, R. (2003): “Technological Innovations in the Context of Public-Private Partnership Projects" unpublished PhD thesis, Royal Institute of Technology, Stockholm.

[27.] Mabogunje, A. (2007): "Thirty Years After: Reflections on the Development Process in Nigeria" Lecture Series, University of Ibadan: Faculty of Social Sciences, 24 November.

[28.] Moran, T. (1986): “The Future of Foreign Direct in the Third World”, in Moran, T. (ed.), invests in Development: New Roles for private capital? Oxford: Transaction Books.

[29.] Moszoro, M. (2008): “The Optimal Capital Structure of Public Private Partnership” IMF Working Papers.ssrn.com.

[30.] Olewe, B. and Anga, J. (1994): Command Administration: The Police Perspective. Enugu: New Generation Books

[31.] Olewe, B. (1995): Development Administration. Aba: Grace Ventures

[32.] Olukoshi, A. (2003): "Towards an Enduring Economic Foundation for Democratic Federalism in Africa" in Gana, A. and Egwu, S. (eds.), Federalism in Africa: framing the National Question, New Jersey: Africa World Press.

[33.] Olukoshi, A. (1993): "General introduction: from crisis to adjustment in Nigeria" in Olukoshi, A. (ed.), The Politics of Structural Adjustment in Nigeria. London: James Currey.

[34.] Oyesiku, O. (2009), "Global Economic Recession Environment and Sustainable Development in Nigeria” Annual, College of Management and Social Sciences Lecture Series 1, Osun State University, Osogbo, 28 April.

[35.] Sampson, E. (2008): "Global Financial crisis: Recession, Depression and other threats" Zenith Economic Quarterly, Vol.3 (4), 68-75.

[36.] Tropman, J. (1976): Strategic Perspectives on Social Policy, London: Pergamon.

[37.] UN/ECE (2000): “Guidelines on Private Public Partnerships for Infrastructure Development" A Paper Presented at United Nations Economic, Geneva.

[38.] Ujo, A. (2007): Development Administration in Nigeria, Kaduna: Joyce Publishers.

[39.] Virginia, T \& Allen, O (2012): "Public-Private Partnership Development" http://a4id.org/PublicPrivate\% 20Partnership.pdf

[40.] World Bank (2007) "Public Private Partnership Units: Lessons for their designs and use in infrastructure"

[41.] Zheng, J. and Lewis,. M (2008): “The Dynamics of Contractual and Relation Governance: The Long-term Public-Private Procurement Arrangements" Journal of Purchasing and Supply Management. 14(1), 43-54 